\title{
Instagram Biodigitroops in Promoting Bio Farma
}

\author{
(Case Study on Bio Farma Internal Influencers)
}

\author{
Yuni Miyansari*, Neni Yulianita \\ Pascasarjana Universitas Islam Bandung \\ UNISBA \\ Bandung, Indonesia \\ *ymiyansari@gmail.com, yulianita.neni@gmail.com
}

\begin{abstract}
Seeing the development of technology and internet in Indonesia and also the great opportunities for promotion, Bio Farma also uses the social media of its employees who are members of Biodigitroops as a means of publicity and company promotion. The research objective was to identify and analyze Biodigitroops Instagram in promoting Bio Farma. This research uses qualitative methods with a case study approach. The results showed that Bio Farma has an internal program by forming an internal influencer named Biodigitroops. Biodigitroops has a duty to promote Bio Farma in their personal accounts according to the characteristics of each member of Biodigitroops. Biodigitroops uses a storytelling style to make the content more attractive to its followers. The results turned out to be positive, namely that many followers who asked about vaccines were included in the comments column and direct messages on Instagram of Biodigitroops members. Biodigitroops members can upload Bio Farma promotional content according to their initiatives without having to wait for content directions from Bio Farma but still have to comply with the social media regulations set by the company.
\end{abstract}

Keywords-promotional content, content posting, company rules, digital influencers

\section{INTRODUCTION}

Business people today benefit greatly from the presence of social media. Research results from We Are Social, in collaboration with Hootsuite, stated that in 2019 there were 150 million social media users in Indonesia. This number has increased by 20 million users compared to research results in 2018 [1]. Instagram has 15 times higher user engagement than Facebook and 25 times higher than Twitter. According to one survey institution, Indonesians can access Instagram 5 to 10 times or more a day. This time is spent scrolling by $72 \%$. Based on this, business people state that Instagram has an effective opportunity to market the products of their business [2]. Therefore, currently, many industries use Instagram as a tool to promote products.

Over time, the development of communication technology makes marketing communication activities can be carried out anywhere, including through new media such as social media. Marketing trends in the world are shifting from conventional (offline) to digital (online). This digital marketing strategy is more prospective because it allows potential customers to obtain all kinds of information about products and transact via the internet. Digital marketing is a promotional activity and market search through online digital media by utilizing various means such as social networking [3]. Seeing the development of technology and internet in Indonesia and the great opportunities for promotion. Bio Farma also uses the social media of its employees who are members of Biodigitroops as a means of publicity and company promotion.

Martius Tomy (2013) states that the benefits of promotion through social media include: 1) Rating features, 2) Unlimited time and space, 3) Easier to attract attention, 4) Minimal promotional costs. It is through the many benefits of social media that many entrepreneurs use social media as a promotional medium, not only large companies but homebased businesses also use social media as a medium [4].

In the last five years, social media has played an important role in promoting products. In this context, a third party called Digital Influencer has emerged. These digital influencers are third parties who have high popularity and do not always come from artists or public figures but have accounts with many followers.

Influencers who actively share their experiences and testimonies through social media have a significant role in creating a better product brand image, as stated by Nova Hariyanti and Alexander Wirajaya (2018) in their journal that Influencer Marketing is seen as one of the best strategies to bring in potential consumers when marketing using social media by utilizing the mass owned by an influencer, an influencer can create a better product brand image and at a lower cost than using an artist's brand endorser or public figures who are already among the top artists [5].

Seeing the power of promoting through digital influencers. Since 2016, Bio Farma's Corporate Communication Division has an internal program that focuses on the millennial generation workforce.. The increasing number of millennials in the company has the potential to manage, empower and collaborate and synergize with millennial employees by making them an effective internal influencer named 
Biodigitroops. Biodigitroops stands for Bio Farma Digital Troops.

Bio Farma is a state-owned company that was established on August 6, 1890. Bio Farma is the only vaccine and antisera producer in Indonesia. Being the only vaccine producer in Indonesia does not mean it has no competitors, because imported vaccines with the same function can be found in Indonesia. Realizing that competition is getting tougher with the entry of various new imported vaccines in Indonesia, of course Bio Farma must optimize its promotional activities. As stated by Michael Ray "The Coordination of all seller-initiated efforts to setup plans of information and persuasion to sell goods and services or promote an idea" [6].

Bio Farma is a company engaged in health services, so in practice its promotion must follow the Regulation of the Minister of Health of the Republic of Indonesia 1787 / MENKES / PER / XII / 2010 concerning Health Service Advertising and Publication. One of the points contained in number 1787 / MENKES / PER / XII / 2010 is stating that an advertisement and / or publication of health services is not allowed if it is advertising hard drugs, psychotropic substances and narcotics [7]. Vaccines are classified in the category of hard drugs which must be purchased using a doctor's prescription and the provider must be a health worker. So that when referring to these regulations, Bio Farma cannot advertise its products commercially either through television and open spaces.

Edwin Garna as Head of the External Relations Section of Bio Farma said that one of Bio Farma's challenges in promotion is that it cannot advertise freely on television like other commercial products, Bio Farma wants to be known but still does not want to violate the applicable rules and what we have done is to create advertisements community service, namely education about the importance of immunization, but we also need another, more massive way, namely forming internal influencers.

The process to form Biodigitroops is not easy. Initially, Bio Farma determined several requirements, including troops having a minimum of 1000 followers or the nano influencer category and being active on social media on various platforms. To convince employees that this is a positive and good thing, of course, requires effort and socialization. Finally, we found 20 employees who are active and have quite a number of followers, ranging from 1000 to 7000 . So that Biodigitroops is categorized as a nanoinfluencer. Nanoinfluencers are defined as influencers with between 1,000 and 10,000 followers. The audience size is small, specialized, but very attractive due to the smallest following of all influencer tiers. Nanoinfleuncers have 6 times of infleuncer engagements because their followers are real and not because of additional fake followers and machines / bots. Those who are closest are more influential in nature of purchasing decisions [8].

Biodigitroops is often invited and involved in various company and ministry events as a content creator and then uploaded on personal Instagram. Here Biodigitroops conducts a promotion called word of mouth. As stated by Evelina and Handayani in their journals, namely in the context of marketing and promotion, digital influencers carry out a promotion function by word of mouth or known as the Word of Mouth (WOM). A statistical survey from Forbes magazine revealed that 92 percent of consumers trust influencers more than traditional advertisements or endorsements through celebrities. So it is not surprising that this digital influencer can carry out its promotional function more effectively through word of post [9].

Lala Arief, who at that time held the position as Head of the Corporate Communication Department of Bio Farma and the initiator of the formation of Biodigitroops, said that changes in the landscape of the audience, digitization and use of the internet are important points that need to be managed. effective as a promotional media for Bio Farma.

Bio Farma itself has corporate social media accounts including Facebook, Instagram, Twitter and Youtube under the account name @biofarmaid. However, Bio Farma is able to see a great power by empowering millennial generation employees who actively use social media, especially Instagram. This is the uniqueness of this case, how Bio Farma carries out its promotional practice by utilizing the Instagram of its internal employees without the need to pay for endorsers or celebrities like other products that are promoted through celebrities. In terms of costs, of course this is more efficient than paying for a Selebgram and from the product knowledge side, internal influencers understand more about the ins and outs of products and companies.

Internal influencers aim to: 1) Empower the millennial generation who are majority in the company to play a constructive and productive role for the benefit of the company, 2) Empower and increase the role of selected employees as internal influencers and effective advocacy. 3) Increase employee engagement with the company by involving non-Public Relations employees, 4) Explore the potential of employees widely in utilizing social media for company development [8]. The expression of employee communication through social media is not only free, but also more sincere and authentic because employees are assets and ambassadors for the company.

Bio Farma promotes its products by utilizing Bio Farma's Instagram Internal Influencer in order to attract more consumer attention to Bio Farma product vaccines. Digital influencers, as a promotional medium that is currently starting to be used by many marketers, are expected by Bio Farma to become one of the valuable instruments in marketing promotion

The phenomenon of influencers continues to grow, studies about influencers in promoting products have started to appear. Companies or business people have begun to use many celebrities and vlogers to promote their products. However, there has not been much discussion about internal influencers who are used to promote the company's products. 
From the statements above, this research focuses on promotional content, content posting, and company rules by using Biodigitroops Instagram in promoting Bio Farma.

\section{METHODS}

This study used a qualitative method with a case study approach with a single case design (holistic) [10]. Data collection techniques used in this research are: interviews, observation, and literature study (books, journals, documents, and the internet). All data has been colected through primary and secondary data. The primary data sources in this study were the head of the company communication division of Bio Farma, the head of the external relations section of Bio Farma, the social media expert staff of Bio Farma, 3 representatives of Biodigitroops members and Biodigitroops followers. The secondary data source is the documented data from tracing the official Biodigitroops Instagram account. Apart from that, secondary data were also obtained from literature reviews, articles, journals and websites on the internet relating to the research conducted.

\section{RESULTS AND DISCUSSION}

Bio Farma is a state-owned company that was established on August 6, 1890. Bio Farma is the only vaccine and antisera producer in Indonesia. Being the only vaccine producer in Indonesia does not mean that Bio Farma has no competitors, because imported vaccines can be found in Indonesia, which is also actively conducting promotional activities. Bio Farma products are quality vaccine products, this is proven by the success of Bio Farma in exporting its products to more than 140 countries. In order to be able to export, vaccine producers must obtain a prequalification certificate from the World Health Organization (WHO). Bio Farma itself is one of about 30 vaccine producers that have been qualified by the World Health Organization. In addition, Bio Farma is also a reference for vaccine producers in Islamic countries.

The rapid development of technology, the digital world and the internet certainly has an impact on the world of marketing. Marketing trends in the world are shifting from conventional (offline) to digital (online). This digital marketing strategy is more prospective because it allows potential customers to obtain all kinds of information about products and transact via the internet.

Seeing the development of technology and internet in Indonesia and the great opportunities for promotion. Bio Farma has an internal program by forming millennial employees as internal ifluencers who are members of Biodigitroops (Bio Farma Digital Troops) as a means of company promotion.

Many companies have carried out their promotional activities using social media. However, not many companies provide guidance to their employees so that they can promote their products on their employees' personal social media. Bio Farma has a corporate social media account with the account name @biofarmaid on Facebook, Instagram, Twitter and
YouTube, one of which functions to promote its products. However, seeing $50 \%$ of its employees are millennial generation, in 2016, Bio Farma has an internal program that focuses on the target audience of the millennial generation, starting with proposing an internal buzzer which is finally outlined in a board of directors' decision letter named Biodigitroops. The use of Instagram Biodigitroops in promoting Bio Farma is unique, which includes promotional content, posting content and company rules.

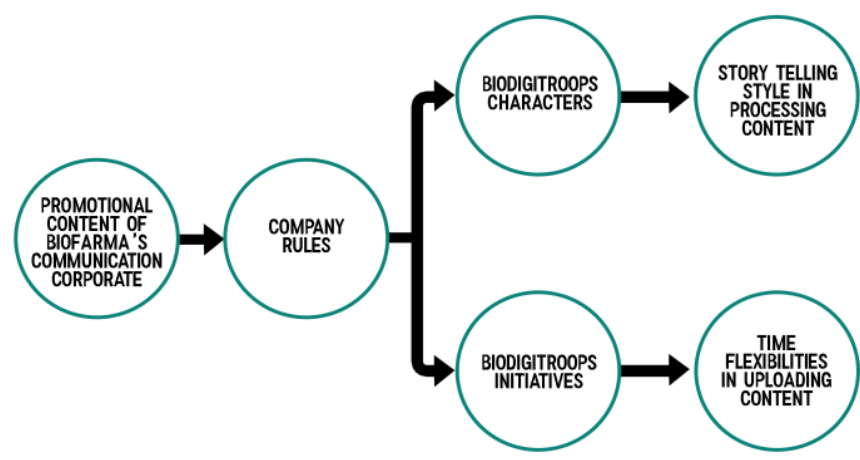

Fig. 1. Bio Farma promotion model by biodigitroops in Instagram

Sources by Authors

\section{A. Promotional Content}

Since the inauguration of Biodigitroops as a promotion agent for Bio Farma, employees who are members of internal influencers have been tasked with entering promotional content on their personal Instagram accounts. Actually, Biodigitroops has other social media such as Facebook and Twitter, but they admit that they are more active in using Instagram.

In order for Biodigitroops to have the ability to build attractive promotional content on its Instagram, Bio Farma conducts training by inviting internal and external sources to enrich their references in social media management as well as convey what can and cannot be done in using social media. Biodigitroops was given a Personal Branding \& Social Media Management Workshop. So that they have the ability to create quality content. From this it can be concluded that Bio Farma is very serious in forming Biodigitroops to become a credible and quality internal influencer.

This is consistent with a study from Augure on three characteristics of influencers: the ability to direct opinions, create reactions and a large community that focuses on a particular topic and the most important part of giving an opinion on a particular subject. An influencer isn't just someone who has a large following and posts content; This influencer is someone who provides a unique opinion and provides meaningful content for his audience. Minduta in Hayden [11].

Influencers gather followers through the content they develop, allowing the audience to know and pay attention to 
the narrative they post. Compared to celebrities or well-known artists, influencers can come from ordinary people, so they are often considered more "authentic" and more "organic". By living a normal life, not as a celebrity or established artist, makes them more natural and get the attention of the audience [8].

Bio Farma's Corporate Communication Department acts as the command center for Biodigitroops. When there is promotional content, Bio Farma's Corporate Communication Department will convey to the Biodigitroops whatsapp group, then internal influencers will recreate the content according to their interests and characteristics, resulting in varied promotional content. Even though the posted content is about the company, Bio Farma directs Biodigitroops to be able to process content according to the personality of each Biodigitrops member on their social media. So that Biodigitroops packs a message with an interesting story and language that is not rigid so that it creates an attachment with Biodigitroops followers so that the message will hit more. Biodigitroops promotes Bio Farma, in their own way and from their own point of view because the company realizes that every individual on social media has a character that his followers are familiar with. This is the uniqueness and promotional appeal of Instagram Biodigitroops.

Edwin Garna as head of the external relations section said that the followers of the @biofarmaid Instagram account are more heterogeneous in terms of age, educational and social background. Meanwhile, Biodigitroops is more concentrated because of their friendship and community. For example, a member of Biodigroops named Iwa. Iwa is a traveler, he often says on his Instagram that it is fun when traveling in a healthy condition and to be healthy we need to be vaccinated, so his followers who also like traveling will get the information, so it is more appropriate.

Bio Farma does not want to impose corporate language to appear on Instagram Biodigiroops. Iwa Kustiwa has a community of travelers. So that Bio Farma created a special hashtag \#vaccinebeforevacation to support and also as an inspiration that the company's promotional content can be personal from their personal experience to make it look attractive. As stated by Lidya and Fitri in their journal entitled The Use of Digital Influencers in Product Promotion, that IG accounts have a lot of followers because they create interesting content. Interesting content is known as Content is the King [9]. There are several things that must be considered so that the content is interesting, namely there is a special theme for each IG account. Because Iwa is a traveler, the promotion using the hashtag \#vaccinebeforevacation is in accordance with its characteristics. Besides that, it is also a subtle invitation to vaccinate before traveling or on vacation.

The Corporate Communication Department directs that the captions written by Biodigitroops members use a story telling style because according to Hafizh Mizwar as Bio Farma's social media expert staff, the power of content on social media is not only visual, but copywriting must also be strong.
Storytelling is very important, especially because promotion from a personal account must be strong in terms of storytelling to tell experiences and testimonials during their use of the company's products. Story Telling is a tool for sharing information, not just telling stories about legends [12].

Story Telling is a tool for sharing information, not just telling stories about legends. Storytelling is more credible than rational argument, statistics and facts. Stories make a topic more real to audiences than most rational persuasion because stories can include arguments in an easy format so that the audience can understand them [12]. The company always provides direction to Biodigitroops about copywriting packaging, that on Instagram they have better stories because the images may not be very attractive, but if there is a strong story it will generate engagement.

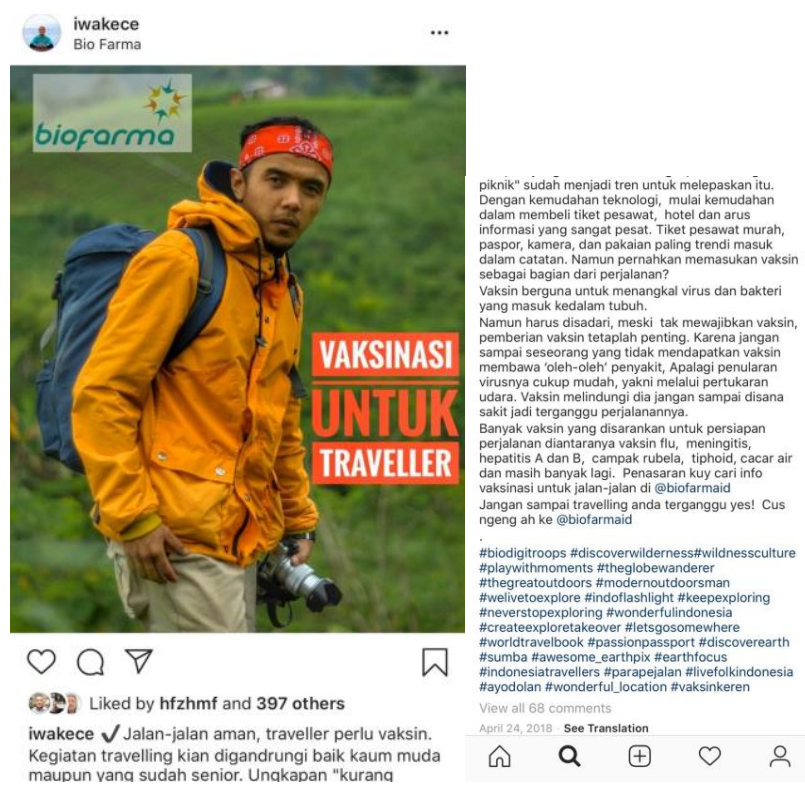

Fig. 2. Instagram @iwakece

The owner of the @iwakece Instagram account is a member of Biodigitroops named Iwa Kustiwa. Currently, Iwa has 7880 followers on Instagram. As an internal Bio Farma influencer who is part of the traveling community, Iwa promotes Bio Farma on his Instagram account according to his hobby as a traveler. From picture 1 we can see Iwa packaged the content very creatively. Visually displays a photo of himself while traveling with the words "Vaccination for Traveler" and is equipped with a caption containing storytelling elements. This is one example that Iwa understands that when uploading Bio Farma's promotional content on Instagram it is important to give his personal touch according to his character as a traveler.

Vaccines are products that are not easily understood by the public. Many pharmaceutical and health terms are difficult to understand by ordinary people. So for Bio Farma, one way to build public awareness of the importance of vaccines as a prevention effort is to build a narrative that tells a story and 
this is what Biodigitroops did. Edwin Garna as the head of Bio Farma's external relations section explained that in the past 5 years, decisions regarding vaccine brands still came from parents, or their closest relatives, but now vaccine decisions come from social media. This is as reported in online media beritatagar.id that a study conducted by Crowdtap, of 1,000 millennial parents showed the results that parents tend to rely on the internet rather than asking and asking for advice from others. As many as 37 percent of mothers believe in social media and 50 percent of fathers do not hesitate to use social media as a tool to carry out their daily roles as head of the household [13]

Bio Farma realizes that its employees have other lives outside of their jobs. They have hobbies and even community. Another Biodigitroops member named Gusnandar, has a hobby of exercising and is part of the running community in Bandung. When promoting the Bio Farma vaccine on his Instagram, Gusnandar told about how to maintain health by diligently doing sports and vaccinations.

\section{B. Posting Content}

Biodigitroops members are given the freedom to be able to create their own content without having to always wait for content distribution from the Corporate Communications Department. Biodigitroops regularly posts even without waiting for content from the Corporate Communications Department. This is an activity that needs to be done because in accordance with the concept of Joseph (2011: 27), there are several social media activities, one of which is Social Media Maintaining. Taking care of social media by posting regularly on social media [14]

Researchers saw the diversity of post content on the Biodigitroops Instagram, there were some content that was uploaded together or near the time, but some were not. It turns out that Biodigitroops does not depend on the provision of content from Bio Farma's Corporate Communication Division, but also based on its own initiative in uploading promotional content on its personal Instagram. When receiving promotional content from Bio Farma's Corporate Communication Division that is received through the wa group, Biodigitroops will continue it by uploading the content on their respective personal Instagram. However, Biodigitroops is also given the freedom to post promotional content. So that Biodigitroops often uploads content on its own initiative. Biodigitroops can inspire content at any time with their own themes, especially if they master the material.

When Biodigitroops requires additional information to answer questions that are entered on its Instagram, Bio Farma is always responsive in providing the direction and information Biodigitroops needs. In addition, Bio Farma also monitors and supervises Instagram Biodigitroops. This is done to observe statements and comments that come from Biodigitroops followers. As a result of the supervision carried out by Bio Farma, it turns out that the promotional content uploaded by Biodigitroops received various responses and positive comments from its followers. Starting from asking about vaccine prices, availability of vaccines and vaccination schedules at Bio Farma.

Chris Huer, an initiator of the Social Media Club, expressed his opinion that in operating social media, there are 4Cs [15]. One of them is Connection [15]. It is important for Biodigitroops to regularly upload Bio Farma content on Instagram to stay connected with its followers. Young, a member of Biodigitroops who works in Bio Farma's Internal Control Unit, said that when Young posted the influenza vaccine on his Instagram, he received several questions from his followers regarding prices, discounts and vaccine service schedules. Likewise, Gusnandar, a member of Biodigitroops who works in the Packaging Department, said that when he posted a promotional discount for the flubio vaccine, many of his friends asked via direct message (dm) asking for prices and how long the discount was valid.

The content uploaded by Biodigitrops is also shared again by its followers. As stated by Johnny, who is a follower of Gusnandar, stated that he had returned to the promotional content that Gusnandar had posted on Instagram. The same thing was conveyed by Annisa, who is a follower of Young, explaining that she had resumed Young's posts regarding the rubella vaccine on her Instagram.

It can be concluded that there is good engagement between Biodigitroops and its followers due to the interaction and followers even re-post the promotional content uploaded by Biodigitroops. The ability to influence like a friend is the credibility an influencer looks for. As stated by Hafizh Mizwar as Bio Farma's social media expert staff, nowadays people believe more in testimonials from their circle of friends, one of which is friendship on Instagram. So that Bio Farma feels the advantages of promotions carried out through internal influencers, namely the promotion is more viral and its followers will not hesitate to ask questions because of the existing friendships.

\section{Company Rules}

As a social media guide for Biodigitroops, Bio Farma sets social media guidelines. Biodigitroops is given the freedom to create promotional content for Bio Farma on Instagram, but Bio Farma establishes rules and guidelines that contain what Biodigitroops can and should not do, even all of its employees as outlined in the company's social media management procedures.

Since the beginning, Bio Farma has briefed Biodigitroops to deliver positive content, not fake news. In addition, Bio Farma always reminds them that they cannot separate themselves as individuals or as employees on social media because whatever they do on their personal Instagram will have an impact on the company's image.

Bio Farma has clear and strict rules for its employees, especially Biodigitroops regarding what can be uploaded and what is not, because not all information in the company can be shared on social media. One of the things that is prohibited is 
uploading pictures or photos in the production work area / laboratory without management permission. As Bio Farma employees, Biodigitroops must follow the ethical rules of using social media in carrying out its role as a Bio Farma promotional agent on their personal social media. Even have to be a role model for other employees.

\section{CONCLUSION}

The results showed 3 main points that researchers found in the use of Instagram by Biodigitroops in promoting Bio Farma, namely:

\section{- Promotional content}

Even though what is posted is content about the company, Bio Farma actually directs Biodigitroops to be able to process promotional content so that it is not stiff so that Biodigitroops does not lose its characteristics or characteristics when posting Bio Farma promotional content on Instagram. In terms of copywriting, Biodigtrops members use a storytelling strategy because the strength of content on social media is not only visual but also uses interesting delivery.

\section{- Post content}

When receiving promotional content from the Bio Farma Corporate Communication Division that was received through the WhatsApp Group, Biodigitroops continued it by uploading the content on their respective personal Instagram. However, Biodigitroops is also given the freedom to post promotional content. So that Biodigitroops often uploads content on its own initiative. Biodigitroops can inspire content at any time with their own themes, especially if they master the material.

\section{- Company Rules}

Biodigitroops is indeed given the freedom to package Bio Farma's promotional content on Instagram, but Bio Farma establishes rules and guidelines that contain what Biodigitroops can and cannot do, even all Bio Farma employees are outlined in the company's social media management procedures.

\section{ACKNOWLEDGMENT}

Thank you to : Directorate of Higher Education, Rector of Bandung Islamic University, All team of Corporate Communication Bio Farma, especially Ibu lala as the initiator of the formation of Biodigitroops.

\section{REFERENCES}

[1] N.N. Arief, Corporate Communication: Praktik Terbaik Komunikasi Perusahaan, Bandung: Simbiosa Rekatama Media, 2020

[2] S. Rohadian \& M.T. Amir, "Upaya Membangun Customer Engagement Melalui Media Sosial Instagram". Journal of Entrepreneurship, Management and Industry (JEMI), 2(4). 2019.

[3] J. Sulaksono, "Peranan Digital Marketing Bagi Usaha Mikro, Kecil, Dan Menengah (Umkm) Desa Tales Kabupaten Kediri”. Generation Journal, 4(1), 41-47. 2020.

[4] M. Tomy, Anda Bos-nya Facebook dan Twiter Staf marketingnya. Yogyakarta: CV. Andi Offset. 2013.

[5] N.T. Hariyanti \& A. Wirapraja, "Pengaruh Influencer Marketing Sebagai Strategi Pemasaran Digital Era Moderen (Sebuah Studi Literatur)". Jurnal Eksekutif, 15(1), 133-146. 2018.

[6] A.M. Morissan, Periklanan komunikasi pemasaran terpadu, Jakarta : Penerbit Kencana. 2010.

[7] S. Hasanah, Ketentuan Iklan Pelayanan Kesehatan Alternatif di Televisi, [Online] Retrieved at: https://www.hukumonline.com/klinik/detail/lt5ad4049e8a0df/ketentuaniklan-pelayanan-kesehatan-alternatif-di-televisi/. Accessed by: 13 September 2019.

[8] N. Arief, Public Relations in The Era of Artificial Intelligence. Bandung: Simbiosa Rekatama Media. 2019.

[9] L.W. Evelina \& F. Handayani, Penggunaan Digital Influencer dalam Promosi Produk (Studi Kasus Akun Instagram @bylizzieparra). Warta ISKI, 1(01), 71. 2018

[10] R.K. Yin, Studi Kasus; desain \& metode. Jakarta: Raja Grafindo Persada, 2013.

[11] K. Hayden, Running Head : Social Influence. 2017.

[12] ToasMasters, ToastMasters Public Speaking, Retrieved November 12 2011, frim http:www.toastmasters-public-speaking.com/oralstorytelling.html. 2010.

[13] F. Silaen, Orang tua milenial sangat tergantung pada media sosial [Online] Retrieved at: https://beritagar.id/artikel/gaya-hidup/orang-tuamilenial-sangat-tergantung-pada-media-sosial. Diakses pada 27 Maret 2019 pukul 20.00 WIB

[14] I.S.R.I. Wulandari, Produk Es Krim Aice. 11(1), 46-51. 2019.

[15] B. Solis, "Engage! The complete guide for brands and businesses to build, cultivate, and measure success in the new web". International Journal of Advertising. 2010. 